\title{
Gender Differences in Stress and Burnout: Department Survey of Academic Family Physicians
}

\section{Abbreviations}

EHR

J Gen Intern Med 36(6):1811-3

DOI: $10.1007 / \mathrm{s} 11606-020-06287-\mathrm{y}$

(c) Society of General Internal Medicine 2020

\section{INTRODUCTION}

Female physicians consistently report higher rates of burnout and lower satisfaction than male physicians, but the etiology is unclear. ${ }^{1}$ Studies conflict regarding the overlap between burnout and depression and to what degree work/home conflicts contribute to burnout differences. We sought to explore gender variations in burnout and health in a large academic family medicine department.

\section{METHODS}

We conducted three annual department-wide assessments $(2017,2018,2019)$ to assess burnout, stress, and satisfaction using anonymous and voluntary Qualtrics surveys distributed via email. The study was deemed exempt by the University of Michigan Institutional Review Board.

Surveys included years since residency, gender, selfreported minority status, the Mini-Z burnout scale; ${ }^{2}$ questions from the Physician Wellness Inventory; ${ }^{3}$ four questions about work-home balance from the Physician Worklife Survey; ${ }^{4}$ and single-item measures of mental and physical health (e.g., "In thinking about my health, I would say my health is...very good, good, fair, or poor").

As the 2017 survey showed striking differences by gender, in 2018, we added exploratory questions (5-point Likert scale from agree strongly to disagree strongly) asking, "How much do you think the following factors [9 listed] contribute to more burnout for women, compared to men?" In both 2018 and 2019 , we queried the presence of a partner at home, partner work status, and children under 6 .

Analyses used Stata/IC 13.1 (College Station, TX) and included summary statistics plus bivariate analysis with

Prior presentations A poster including some of the results was presented at the American Association of Medical Colleges "Learn, Serve, Lead" annual conference, Nov. 9, 2019.

Received March 18, 2020

Accepted October 5, 2020

Published online October 26, 2020
Fisher's exact test for cell sizes $\leq 5$ and Chi-squared for larger cell sizes.

\section{RESULTS}

Of eligible faculty, 77 of 84 (92\%) completed the survey in 2017, 91 of 96 (95\%) in 2018, and 81 of $105(77 \%)$ in 2019. Variables had up to $9 \%$ missing data in $2017,8 \%$ in 2018, and $3 \%$ in 2019. In 2019, 51 respondents (64\%) identified as women. Women were more likely to have completed residency within 10 years ( $n=24$ women, $47 \%$ versus $n=6$ men, $21 \% ; p=0.019)$. One-fifth of faculty $(n=16,20 \%)$ identified as an under-represented minority.

Women were more likely to report burnout in 2017 (52\% women versus $24 \%$ men, $p=0.022$ ), 2018 (38\% versus $15 \%$, $p=0.043)$, and 2019 (34\% versus $31 \%, p=0.787)$. Female faculty $(n=38,83 \%)$ were more likely than men $(n=9,38 \%$, $p<0.0005)$ to have a partner working full-time versus parttime or not at all and to have young children at home $(n=21$ women, $41 \%$ versus $n=4$ men, $14 \% ; p=0.013$ ). Neither partner work status nor children were associated with burnout. In all years, men were significantly more likely to report "good" or "very good" physical and mental health (Table 1). Women had worse scores on all work-life balance questions (not statistically significant). Faculty perceptions on factors contributing to female burnout varied by gender (Fig. 1).

\section{DISCUSSION}

This study identifies different family structures and self-rated health among physicians by gender. Balancing home and work lives may influence, but does not fully explain, increased burnout among women. ${ }^{5}$ Our findings of higher burnout and worse mental health among female physicians mirror those of other research. ${ }^{1}$

While men and women both agreed female physicians have more home responsibilities, they disagreed on other burnout contributors among women physicians. Prior studies show older age, good mental health, more children, and low home stress predict greater work satisfaction for women. ${ }^{6}$ As women are more likely to have a partner working full-time, they face greater need for work flexibility and may have different priorities and strategies to mitigate job stress. Increased worry about work after hours could be addressed through institutional changes (more protected work time for administrative 
Table 1 Health-Related Measures: Those Reporting as "Very Good" or "Good"

\begin{tabular}{|c|c|c|c|c|c|c|c|c|c|}
\hline & \multicolumn{3}{|l|}{2017} & \multicolumn{3}{|l|}{2018} & \multicolumn{3}{|l|}{2019} \\
\hline & $\begin{array}{l}\text { Men, } \\
n(\%)\end{array}$ & $\begin{array}{l}\text { Women, } \\
n(\%)\end{array}$ & $p$ value & $\begin{array}{l}\text { Men, } \\
n(\%)\end{array}$ & $\begin{array}{l}\text { Women, } \\
n(\%)\end{array}$ & $p$ value & $\begin{array}{l}\text { Men, } \\
n(\%)\end{array}$ & $\begin{array}{l}\text { Women, } \\
n(\%)\end{array}$ & $p$ value \\
\hline Physical health & $24(96)$ & $35(76)$ & $0.032 *$ & $23(82)$ & $36(64)$ & 0.129 & $24(83)$ & $34(68)$ & 0.192 \\
\hline Mental health & $23(92)$ & $30(65)$ & $0.013 *$ & $26(93)$ & $42(75)$ & 0.075 & $26(90)$ & $36(71)$ & 0.057 \\
\hline $\begin{array}{l}\text { Both physical and mental } \\
\text { health }\end{array}$ & $22(88)$ & $28(61)$ & $0.028 *$ & $23(82)$ & $30(54)$ & $0.016^{*}$ & $23(79)$ & 27 (53) & $0.030 *$ \\
\hline
\end{tabular}

$* p<0.05$

duties, fewer demands outside of work hours, and colleague coverage of duties) and personal skills training in setting boundaries.

The exploratory nature of our cause-of-burnout questions is a limitation. Our study focused on a single department. Respondents included more women and minority faculty than the family physician workforce nationally, likely reflecting recent department growth and hiring of recent residency graduates and very few faculty resignations or retirements in this time. Strengths include a relatively a high response rate.

Strategies to mitigate burnout should recognize that burnout phenotypes and effective interventions may differ by gender. Given human and economic risks of burnout in healthcare, we must identify the most stressful aspects of physician work, understand how these vary for men and women, and design interventions which better respond to individual needs.

Acknowledgments: The authors are grateful for the assistance of Ms. Katie Grode in the manuscript preparation.
Katherine J. Gold, MD MSW MS ${ }^{1,2}$

Angela L. Kuznia, MD MPH ${ }^{1}$

Anna R. Laurie, $M D^{1}$

Christa B. Williams, $M^{1}$

${ }^{1}$ Department of Family Medicine, University of Michigan,

1018 Fuller Street, Ann Arbor, MI 48104-1213, USA

${ }^{2}$ Department of Obstetrics and Gynecology, University of Michigan,

1500 East Medical Center Drive, Ann Arbor, MI 48109-0276, USA

Corresponding Author: Katherine J. Gold, MD MSW MS; Department of Family Medicine, University of Michigan, 1018 Fuller Street, Ann Arbor, MI 48104-1213, USA (e-mail: ktgold@umich.edu).

\section{Compliance with Ethical Standards:}

Conflict of Interest: The authors declare that they do not have a conflict of interest.

\section{How much do you agree that female physicians...}

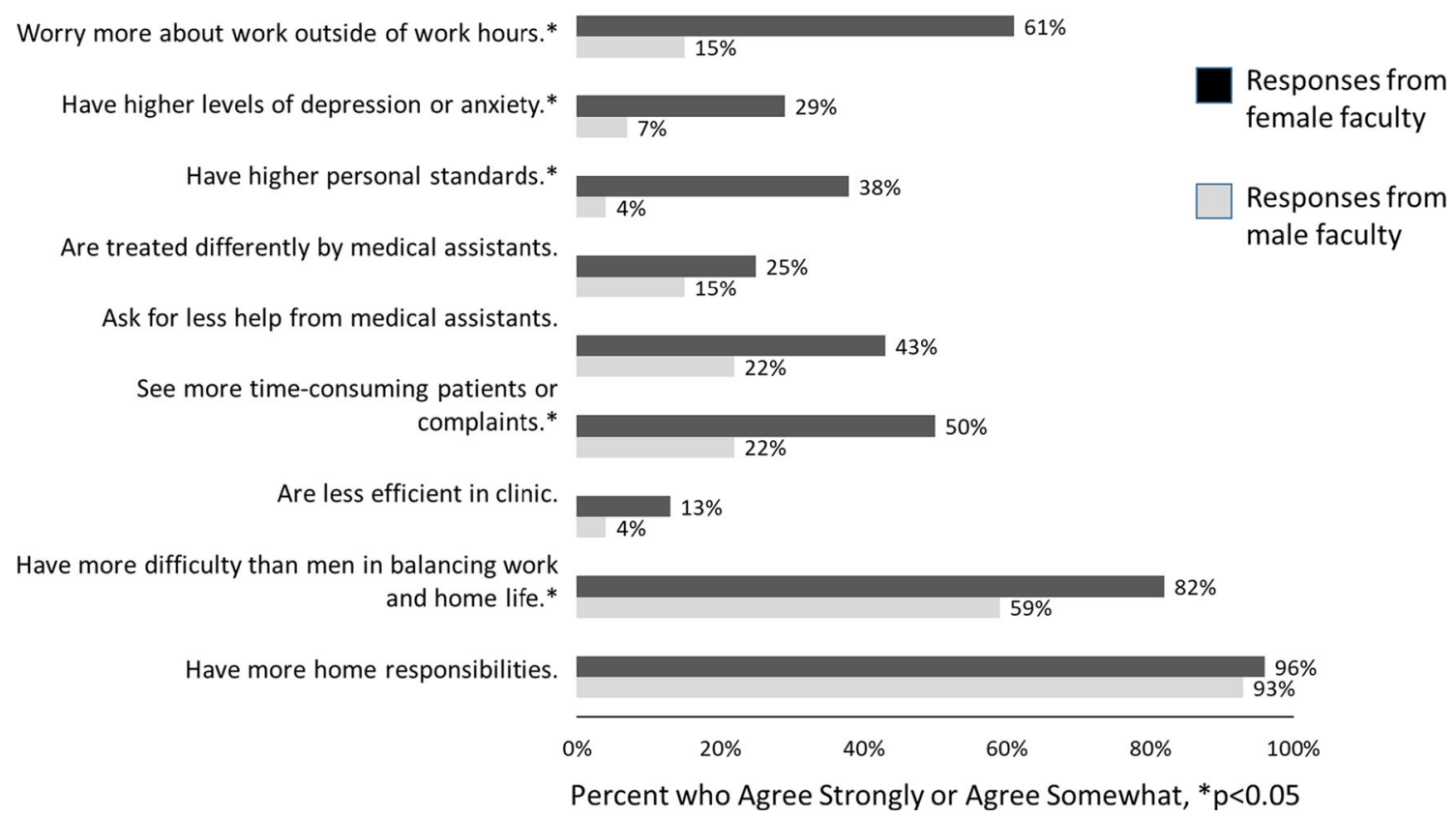

Figure 1 Perceptions of contributors to burnout among female physicians, by gender. 


\section{REFERENCES}

1. Rabatin J, Williams E, Baier Manwell L, Schwartz MD, Brown RL, Linzer M. Predictors and Outcomes of Burnout in Primary Care Physicians. J Prim Care Community Health. Jan 2016;7(1):41-43.

2. Linzer M, Konrad TR, Douglas $\mathbf{J}$, et al. Managed care, time pressure, and physician job satisfaction: results from the physician worklife study. $J$ Gen Intern Med. Jul 2000;15(7):441-450.

3. Eckleberry-Hunt J, Kirkpatrick H, Taku K, Hunt R, Vasappa R. Relation Between Physicians' Work Lives and Happiness. South Med J. Apr 2016;109(4):207-212.

4. Williams ES, Konrad TR, Linzer M, et al. Refining the measurement of physician job satisfaction: results from the Physician Worklife Survey.
SGIM Career Satisfaction Study Group. Society of General Internal Medicine. Med Care. Nov 1999;37(11):1140-1154.

5. Rizvi R, Raymer L, Kunik M, Fisher J. Facets of career satisfaction for women physicians in the United States: a systematic review. Women Health. 2012;52(4):403-421.

6. Frank E, Dingle AD. Self-reported depression and suicide attempts among U.S. women physicians. Am J Psychiatry. Dec 1999;156(12):1887-1894.

Publisher's Note: Springer Nature remains neutral with regard to jurisdictional claims in published maps and institutional affiliations. 